\title{
Choriocarcinoma - Varied Presentations
}

\author{
SN BEGUM
}

Summary:

Choriocarcinoma is a highly malignant tumour that originates in developing trophoblast of pregnancy. It is a potentially fatal disease but current management protocol has turned the prognosis highly favourable.

Gestational choriocarcinoma is not a rare disease in our country. Various mode of presentation sometimes makes it difficult to diagnose.

\section{Introduction:}

Choriocarcinoma is a highly malignant epithelial tumour arising from the trophoblastic tissue of any gestational event. ${ }^{1}$ It is a potentially fatal disease, but availability of different diagnostic aid ( ultrasonogram, serum $\beta$ hCG) and its unique sensitivity to chemotherapy has turned the prognosis highly favourable.

It is one of the rare human malignancy which is completely curable even with wide spread metastasis².

It has an incidence of 0.05 to 0.23 per thousand live births. The frequency of the disease is estimated as 1 in 30,000 pregnancies in the West and 1 in 11,000 pregnancies in Oriental communities. ${ }^{3}$

Preceding gestational events are hydatidiform mole (50\%), term pregnancy (20\%), non molar abortion (5\%) and ectopic pregnancy (5\%). ${ }^{4}$

Patients may present with irregular vaginal bleeding, amenorrhoea, abdominal or vaginal swelling or symptoms of metastasis like haemoptysis. ${ }^{4}$ It can virtually spread anywhere in the body through haematogenous or lymphatic route. Most commonly it spreads to lungs (80\%), lower genital tract (cervix, vagina, vulva), brain and liver. ${ }^{5}$ It can spread to small bowel producing intestinal obstruction, renal mass with hematuria, splenic metastasis with intraperitoneal bleeding with severe anaemia. ${ }^{3.6 .7,8}$

Address of Correspondence: Prof. Dr. Shamsun Nahar Begum, Professor \& Head, Dept. of Obs. \& Gynae, Sir Salimullah Medical College and Mitford Hospital, Mobile - 01712037415, Emailsnhena@yahoo. Com

Received: 8 January, 2012

Accepted: 11 June, 2012
Eleven cases of choriocarcinoma were presented here along with treatment modalities and prognosis. Two patients expired during treatment while other respond well with chemotherapy. Early diagnosis and appropriate treatment have better prognosis.

(J Bangladesh Coll Phys Surg 2012; 30: 145-150)

Gestational trophoblastic tumour always contain only paternal genes as such they are considered to an allograft in the maternal host. ${ }^{9} \mathrm{~A}$ few postmolar choriocarcinomas are biparental, and are considered to represent 'new pregnancies' or 'carcinoma $a b$ initio'. ${ }^{10,11}$ Most of the choriocarcinoma patients of belong to poor socioeconomic class and that may directly related to poor nutritional status .

The clinical presentation, treatment modalities and outcome of 11 cases of choriocarcinoma are discussed here.

\section{Methods:}

This prospective study on 11 cases of choriocarcinoma with varied clinical features was undertaken in Sylhet MAG Osmani Medical college.

All data regarding clinical presentation, investigation and treatment with outcome was recorded meticulously for analysis.

\section{Result:}

Sociodemographic characteristic of the patients were presented in Table I. Mean age of the patient were 33.39 yrs (range18-46yrs), among them six were $>40$ years of age. $73.75 \%$ were multipara (n-8) out of which four were grandmulti. All but one belongs to poor social class. Blood group was $\mathrm{O}$ in seven cases while rest have $\mathrm{A}$ or $\mathrm{AB}$ group.

Time interval between antecedent pregnancy and diagnosis of disease varies from 3months to 13 yrs. Antecedent pregnancy events were term pregnancy (n5), abortion (n-5) and molar pregnancy (n-1) in this study. 
Clinical presentation was depicted in Table II. Irregular per vaginal bleeding was the common presentation in all case. Other clinical features were lower abdominal pain (case2,3,4,5,6), bleeding from vaginal growth (case1,8) and Shock (case1,4). Two patients (case 4,6) present with acute abdomen for internal haemorrhage needed emergency laparotomy. Uterus was enlarged (about 10$20 \mathrm{~cm}$. size) in seven cases due to myometrial involvement and misdiagnosed as fibroid uterus by ultrasonogram. Case 7 was diagnosed as cervical fibroid by USG. Serum $\beta$-hCG level varies from 412-15,00,000 miu/ml. Pulmonary metastasis was present in 7 cases. Case 1 had metastasis in vagina, lungs and brain. Histopathology showing features of choriocarcinoma in 8 cases.

Regarding treatment 63.63\% (n-7) patients had total abdominal hysterectomy (TAH) due to severe bleeding with extensive involvement of myometrium. Four patient had internal haemorrhage as the growth invade the uterine wall. Chemotherapy was given in $81.80 \%$ of cases. EMA-CO regime was given in six patient while three received MTX. Both surgery (TAH) and chemotherapy was needed in seven cases.

Regarding treatment outcome, seven had good recovery while two patient expired. Two patient lost to follow-up. Case no. 6 expired suddenly on $2^{\text {nd }}$ POD following TAH due to respiratory problem (? pul.embolism). Case no.8 having vaginal and pulmonary metastasis with high $\beta$ hCG level, treated with surgery (TAH) and chemotherapy but the patient succumb suddenly on $7^{\text {th }}$ POD.

Autopsy examination was needed to confirm the cause of death in such cases.

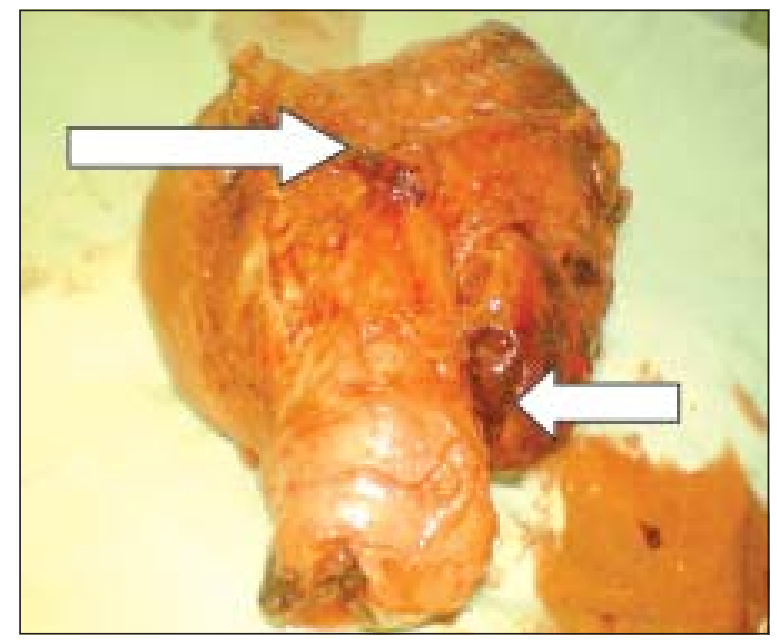

Fig.-1: Haemorrhagic growth in lat. and ant wall of ut.(case3)

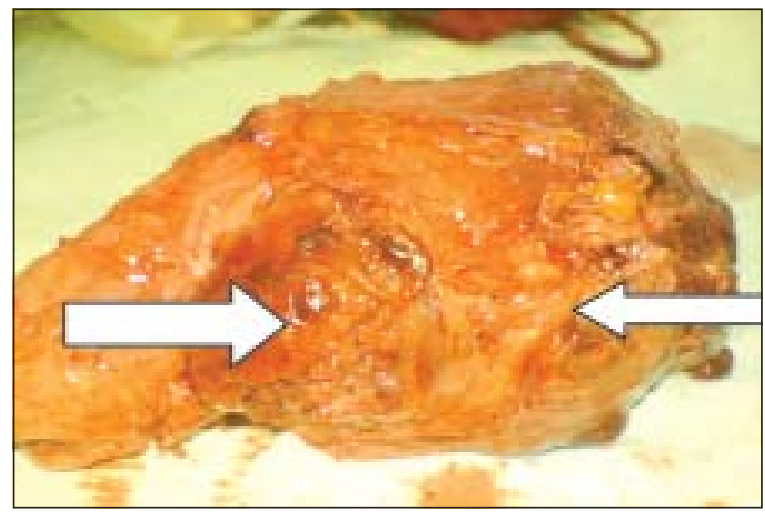

Fig.-2: Haemorrhagic growth (case4)

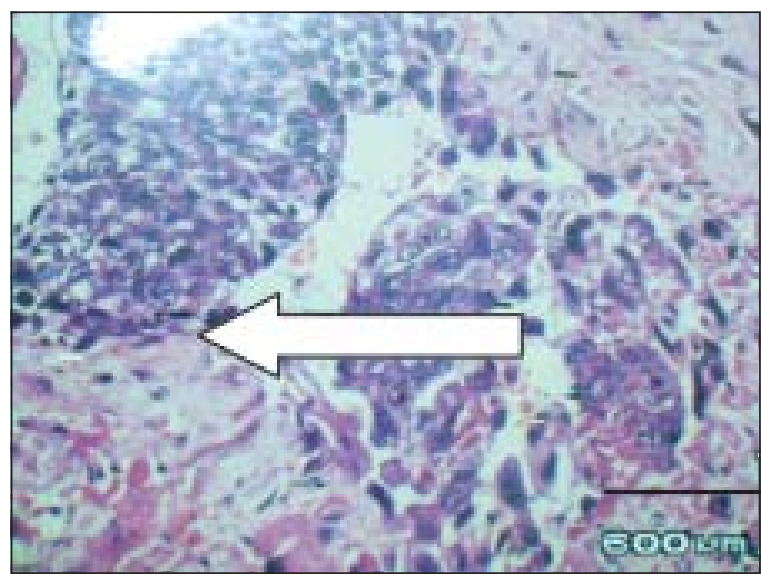

Fig.-3: Photomicrograph of choriocarcinoma(case4)

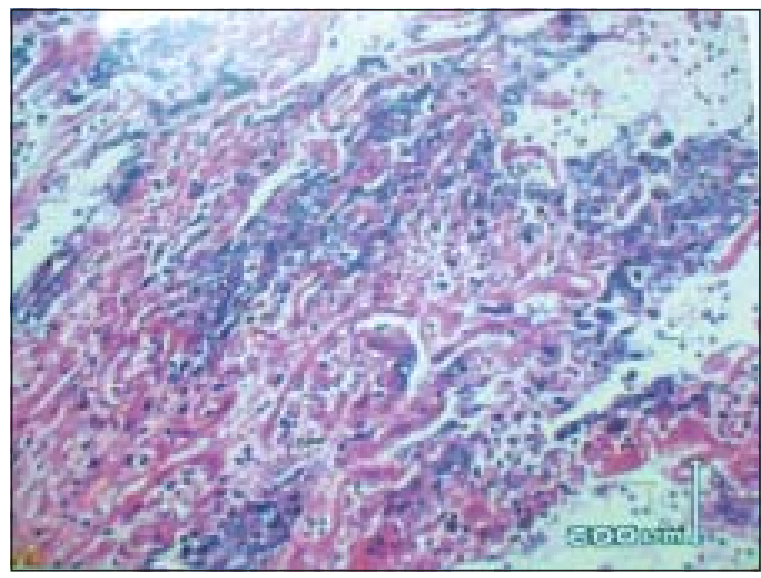

Fig.-4: Photomicrograph (low power) (case5) 


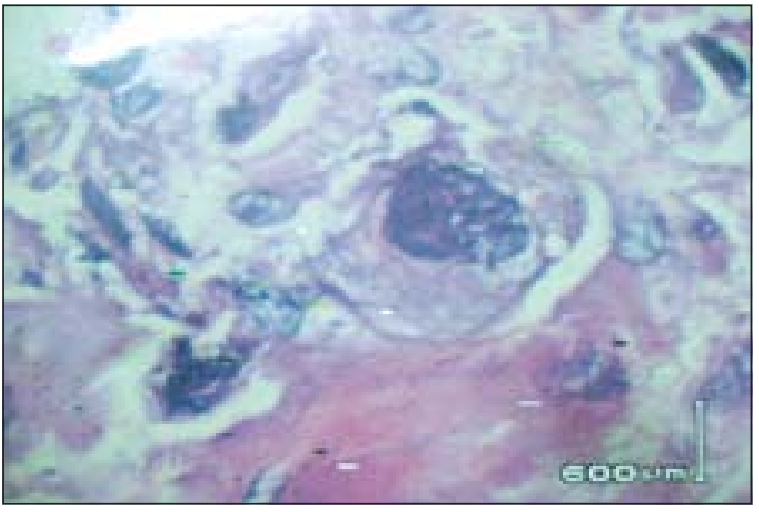

Fig.-5: Photomicrograph (high power)(case5)

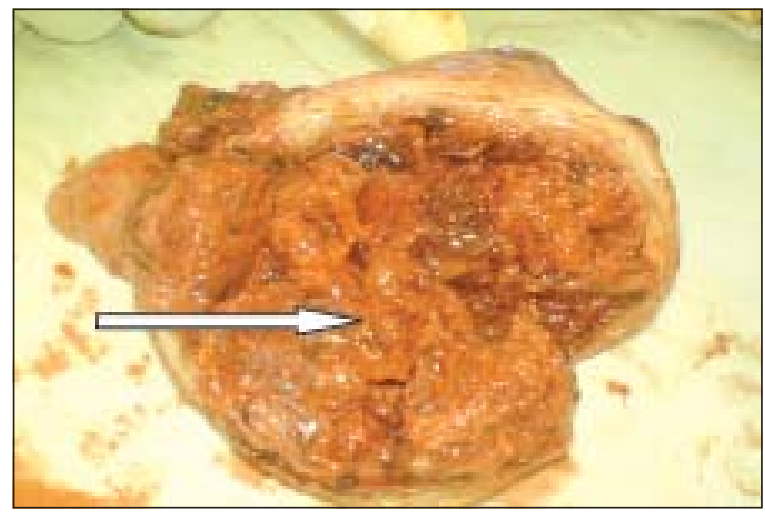

Fig.-6: Cut section of ut. showing growth(case-6) Fig.7 Growth in vagina.(case-8)

Table-I

\begin{tabular}{|c|c|c|c|c|c|c|}
\hline \multicolumn{7}{|c|}{ Sociodemographic profile of cases } \\
\hline $\begin{array}{l}\text { Case } \\
\text { no. }\end{array}$ & Age & Parity & $\begin{array}{c}\text { Socioeconomic } \\
\text { condition }\end{array}$ & $\begin{array}{l}\text { Interval of preg. } \\
\quad \& \text { disease }\end{array}$ & $\begin{array}{l}\text { Antecedent } \\
\text { pregnancy }\end{array}$ & $\begin{array}{l}\text { Blood } \\
\text { group }\end{array}$ \\
\hline 1 & 40 & $2+0$ & Poor & 13yrs & Term preg. & $\mathrm{O}$ \\
\hline 2 & 20 & $0+1$ & Poor & $1 \mathrm{yrs}$ & H.Mole & $\mathrm{O}$ \\
\hline 3 & 40 & $7+0$ & Poor & $7 \mathrm{yrs}$ & Term preg & A \\
\hline 4 & 20 & $0+1$ & Poor & 1.6yrs & Abortion & $\mathrm{O}$ \\
\hline 5 & 26 & $4+0$ & Poor & 1.6yrs & Term preg & $\mathrm{O}$ \\
\hline 6 & 45 & $8+1$ & Poor & $10 \mathrm{yrs}$ & Term preg. & $\mathrm{O}$ \\
\hline 7 & 18 & $0+1$ & Poor & 3 month & Abortion & A \\
\hline 8 & 25 & $1+1$ & Poor & $1 \mathrm{yrs}$ & Abortion & $\mathrm{O}$ \\
\hline 9 & 42 & $3+1$ & Poor & 1.6yrs & Abortion & $\mathrm{AB}$ \\
\hline 10 & 45 & $10+1$ & Middle class & 2.6yrs & Abortion & A \\
\hline 11 & 46 & $7+1$ & Poor & 11 yrs & Term preg. & $\mathrm{O}$ \\
\hline
\end{tabular}


Table showing age of the patient were between 1846yrs, parity 0-10, mostly following term pregnancy, majority were from poor class family, common blood group were $\mathrm{O}(\mathrm{OO})$.

Table-II

\begin{tabular}{|c|c|c|c|c|c|}
\hline \multicolumn{6}{|c|}{ Management outcome of cases- } \\
\hline Case no. & Clinical presentation & Metastasis & Investigations & Treatment & Outcome \\
\hline 1 & $\begin{array}{l}\text { PVB, } \\
\text { Vaginal growth } \\
\text { Shock,. }\end{array}$ & $\begin{array}{l}\text { Vagina, } \\
\text { Lungs, } \\
\text { Brain }\end{array}$ & $\begin{array}{l}\beta \text {-hCG - 107,000 } \\
\text { CXR-pul.matastasis } \\
\text { SOL in brain }\end{array}$ & $\begin{array}{l}\text { EMACO } \\
\text { RT }\end{array}$ & good \\
\hline 2 & $\begin{array}{l}\text { Irreg. PVB, } \\
\text { Severe LAP \& } \\
\text { mass abd. }\end{array}$ & myometrum & $\begin{array}{l}\beta \text {-hCG - 25,300 } \\
\text { USG-Ut.growth } \\
\text { (highly vascular) }\end{array}$ & MTX & good \\
\hline 3 & $\begin{array}{l}\text { PVB, } \\
\text { LAP, mass abd. } \\
\text { severe anaemia }\end{array}$ & $\begin{array}{l}\text { Lungs, } \\
\text { myometrum }\end{array}$ & $\begin{array}{l}\beta \text {-hCG - 30,500 } \\
\text { USG-RPC/fibroid } \\
\text { CXR-pul.matastasis } \\
\text { Histopath.-chorio-ca }\end{array}$ & $\begin{array}{l}\text { TAH, } \\
\text { EMACO }\end{array}$ & $\begin{array}{l}\text { Lost to } \\
\text { follow up }\end{array}$ \\
\hline 4 & $\begin{array}{l}\text { PVB, mass abd. } \\
\text { Acute abd., } \\
\text { shock }\end{array}$ & myometrum & $\begin{array}{l}\beta \text {-hCG 89,425 } \\
\text { USG- ut.mass . } \\
\text { Histopath.-chorio-ca }\end{array}$ & TAH,EMACO & Good \\
\hline 5 & $\begin{array}{l}\text { PVB, LAP, } \\
\text { Severly anaemia } \\
\text { mass abd. }\end{array}$ & $\begin{array}{l}\text { Lungs } \\
\text { myometrum }\end{array}$ & $\begin{array}{l}\beta \text {-hCG - 41,600 } \\
\text { CXR-pul.matastasis } \\
\text { USG- ut.mass . } \\
\text { Histopath.-chorio-ca }\end{array}$ & $\begin{array}{l}\text { TAH, } \\
\text { Refuse chemo }\end{array}$ & $\begin{array}{l}\text { Lost to } \\
\text { follow up }\end{array}$ \\
\hline 6 & $\begin{array}{l}\text { PVB, Acute abd. } \\
\text { haemoptysis, } \\
\text { anaemia }\end{array}$ & $\begin{array}{l}\text { Lungs, } \\
\text { myometrum }\end{array}$ & $\begin{array}{l}\beta \text {-hCG - } 711 \\
\text { USG- ut.mas } \\
\text { CXR-pul.matastasis } \\
\text { Histopath.-chorio-ca }\end{array}$ & TAH & Expired \\
\hline 7 & $\begin{array}{l}\text { PVB, fever } \\
\text { mass in cx, }\end{array}$ & $\begin{array}{l}\text { Lungs, } \\
\text { cervix }\end{array}$ & $\begin{array}{l}\beta \text {-hCG - 1,60,000 } \\
\text { USG-Cx. Fibroid } \\
\text { CXR-pul.matastasis }\end{array}$ & EMACO & Good \\
\hline 8 & $\begin{array}{l}\text { PVB, cough, } \\
\text { resp. distress } \\
\text { vag.growth }\end{array}$ & $\begin{array}{l}\text { Lung s } \\
\text { Vagina. }\end{array}$ & $\begin{array}{l}\beta \text {-hCG - 15,00,000 } \\
\text { CXR-pul.matastasis. } \\
\text { Histopath.-chorio-ca }\end{array}$ & MTX & Expired \\
\hline 9 & $\begin{array}{l}\text { PVB, Cough, } \\
\text { resp.distress, wt. loss }\end{array}$ & $\begin{array}{l}\text { Lungs, } \\
\text { myometrium }\end{array}$ & $\begin{array}{l}\beta \text {-hCG - } 422 \\
\text { USG- Ut,mass } \\
\text { CXR-pul.matastasis. } \\
\text { Histopath.-chorio-ca }\end{array}$ & $\begin{array}{l}\text { TAH } \\
\text { EMACO }\end{array}$ & Good \\
\hline 10 & $\begin{array}{l}\text { PVB } \\
\text { Enlarged ut.. }\end{array}$ & myometrium & $\begin{array}{l}\beta \text {-hCG - 64,000 } \\
\text { USG- Ut.mass } \\
\text { Histopath.-chorio-ca }\end{array}$ & $\begin{array}{l}\text { TAH, } \\
\text { EMACO }\end{array}$ & Good \\
\hline 11 & $\begin{array}{l}\text { PVB } \\
\text { Enlarged ut }\end{array}$ & myometrium & $\begin{array}{l}\beta \text {-hCG - 107,640 } \\
\text { USG- Ut.mass } \\
\text { Histopath.-chorio-ca }\end{array}$ & $\begin{array}{l}\text { TAH, } \\
\text { MTX }\end{array}$ & Good \\
\hline
\end{tabular}




\section{Discussion:}

11 cases Choriocarcinoma were admitted and studied over a period of 20 months in Sylhet MAG Osmani Medical College Hospital . This study showed a higher frequency of gestational choriocarcinoma in this region.

Most of the patient were from poor socioeconomic class. Higher frequency of choriocarcinoma in this deprived group may be related to poor nutrition.

Association with dietary deficiencies was also reported by Berkowitz et al who noted the progressively increasing incidence of GTD with decreasing level of dietary carotene and animal fat. This correlates with the study in Pakistan where similar socioeconomic condition is prevaling ${ }^{12}$

In this study $73.75 \%$ (n-8) patients were multipara out of which four were grandmulti. Mean age of the patients were 33.39yrs (range18-46yrs), among them six were $>40 y$ rs of age. Abnormal ovulation and fertilization in older women may predispose to choriocarcinoma. Knowledge of antecedent pregnancy is important because prognosis depends upon it. Choriocarcinoma commonly follows molar pregnancy. But in this study 5 patients had abortion, 5 had delivery at term \& only one had molar pregnancy. However 3 of these patients labeled as abortion, no details of clinical findings or histopathology of conceptus were available. So this misdiagnosis causing delay in initiation of treatment and thus influence prognosis. In a study by RN Baergen et. al showed that age greater than 35 years, interval from antecedent pregnancy of $>2$ years, and prior term pregnancy were the significant prognostic factors. ${ }^{14}$

Haemoptysis in pulmonary metastasis frequently confused with tuberculosis which is common in our country making diagnosis late. Choriocarcinoma is a highly malignant neoplasm that metastasize readily to vagina, lungs, liver \& brain. Rarely it can metastasize in intestine, spleen, kidney and lymph nodes.

In this study site of metastasis was lungs (n-7), vagina $(n-2)$, brain (n-1) and cervix (n-1). Uterine myometrium was involved in 8 cases. $\beta$ hCG level was high in 9 cases. Two patients (case 6,9) had low $\beta$-hcg $(<1000 \mathrm{iu} / \mathrm{L})$ presented with irregular $\mathrm{p} / \mathrm{v}$ bleeding, uterine mass \& pulmonary metastasis. Case 6 had emergency hysterectomy for severe intra-peritonial haemorrhage but she suddenly expired on $7^{\text {th }}$ POD ( ? pul. embolism). Case 9 also had hysterectomy \& chemotherapy. Both the cases were probably metastatic placental site trophoblastic tumour (PSTT) which is a variant of GTD. In PSTT exaggerated invasion of trophoblastic tissue in the myometrium necessitate treatment by hysterectomy. Metastatic PSTT need chemotherapy in addition to surgery. ${ }^{13}$

Intraperitoneal haemorrhage following spontaneous perforation of uterus may simulate ectopic pregnancy as in case 5. Rapid growth \& haemorrhage makes the tumour a medical emergency. In this study, 63.63\% (n7) cases had total abdominal hysterectomy(TAH) which has similarity with the study by RN Baergen where hysterectomy with or without salphingoophorectomy was performed in $85 \%$ of cases. . Five cases developed acute abdomen due to intra-peritoneal bleeding needed hysterectomy. 5cases were treated with combined surgery and chemotherapy. Six patients received EMACO therapy and responded well. Two patients died suddenly probably due to pulmonary embolism.

Anatomical staging emerged as the most important prognostic factor. Other significant factors include interval from previous pregnancy, prior term pregnancy, high level, deep myometrial invasion, high mitotic rate, coagulation necrosis. Time interval between antecedent pregnancy and onset of chemotherapy is also a crucial prognostic factor. The number and size of metastasis will obviously influence the response, but the site is also important. Tumour involving the brain, liver and gastrointestinal tract have a poor response. The level of $\beta$ hCG prior to starting of treatment is important in predicting the response to therapy. Patients with serum $\beta$ hCG levels above $100,000 \mathrm{miu} / \mathrm{ml}$ have a poor response ${ }^{15}$.

\section{Conclusions:}

Gestational choriocarcinoma is not a rare disease in our country. It is a life threatening disease but complete remission can be obtained in majority of patients by appropriate chemotherapy.

Choriocarcinoma should be suspected when there is irregular uterine bleeding following hydatidiform mole, abortion or pregnancy. Prognosis depends upon early diagnosis and management. High index of suspicion and continued vigilance is required for early detection \& treatment in order to reduce choriocarcinoma mortality. These patients should be managed by team of experts. It is important to individualize treatment for GTN based 
upon risk factor. Using less toxic therapy for low risk cases and aggressive multi agent therapy for high risk cases. As choriocarcinoma usually affects poor women, provision of free medical care should be considered to save their lives.

Advanced maternal age is a high risk factor regarding prognosis. Trend of large size families and pregnancy at the extremes of reproductive age should be discouraged by motivation and provision of effective family planning services. Development of Molar Card and its implementation is an essential step for follow up and early detection of post molar complications.

\section{References:}

1. Rustin GJS. Trophoblastic diseases. In: Shaw Gynaecology. Shaw RW, Soutter WP, Stanton SL.(Editors ),second edition Churchill Livingstone, United Kingdom; 1997; 605-14.

2. Goldstein DP, Berkowitz RZ. Current management of complete and partial molar pregnancy. J Reprod Med 1994; 39: $139-42$

3. Antony T, Edward N, Mark P. Unusal case of choriocarcinoma occuring 12 months after delivery. British Medical Journal; 1998; 1 -2.

4. Phlip S, Micheal S. Trophoblastic disease. In: Dewhurst's Textbook of Obstetrics and Gynaecology for Postgraduates, Edmonds DK (editor). Seventh edition, Blackwell publishing, Oxford; 2007 : 117-124.

5. Li MC. Trophoblastic disease: natural history, diagnosis and treatment. Ann Intern Med. 1971; 74:102-12.
6. Balagopal P, Pandey M, ChandramohanK, Somanathan T, Kumar A. Unusual presentation of choriocarcinoma.World J surg oncol. 2003;1:4.

7. Alireza Kheradmand. Choriocarcinoma presenting as bilateral renal tumour -a case report. Urology Journal UNRC/IUA; 2005; 2(1).

8. Chaturvedi M, Videeswar P, Pandit AA. Metastatic choriocarcinoma: an unusual cause o severe anaemia.J Postgrad Med. 2005;51:230-231

9. Information for Medics-Gestational Trophoblastic Tumours. Online Web Pages 1-5, cited May 13, 2003. http:/ www.hmole-chorio.org.uk/Medics GTT.htm.

10. Acosta Sison H. Can the implanting trophoblast of the fertilized ovum develop immediately into choriocarcinoma? Am J Obstet Gynecol. 1955;69:442-4.

11. Acosta Sison H. Ab initio choriocarcinoma: two unusual cases. Obstet Gynaecol NY. 1959;13: 350-352.

12. Raisa Izhar, Azizun nisa. Prognosis of gestational choriocarcinoma at Khyber teaching hospital, Peshwar. http:/ /www.ayubmed.edu.pk/JAMC/PAST/15-2/Raisa\% 20 choriocarcinoma.htm

13. Nadereh B,Fatemeh G,Malihe H. Long term remission of metastatic placental site trophoblastic tumor(PSTT): case report and review of literature.World J Surg Oncol.2005;3:34.

14. R N.Baergen, J l.Rutgers, R h.Young, K Osann, R e.Scully. Placental site trophoblastic tumor: A study of 55 cases and review of the literature emphasizing factors of prognostic significance. Gynaecological oncology (100). 2006; 511-520

15. Gestational trophoblastic disease. In. Jeffcoate's Principales of Gynaecology, seventh international edition(2008), edts. Pratap Kumar and Narendra Malhotra, Jaypee Brothrers Medical publishers. 2008;161-171. 